\title{
The distribution and elevated solubility of lead, arsenic and cesium in contaminated paddy soil enhanced with the electrokinetic field
}

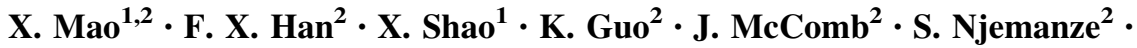 \\ Z. Arslan' ${ }^{2}$ Z. Zhang ${ }^{1}$
}

Received: 30 July 2015/Revised: 15 March 2016/Accepted: 3 May 2016/Published online: 17 May 2016

(C) Islamic Azad University (IAU) 2016

\begin{abstract}
The objectives of this study were to investigate fractionation, solubility and potential bioavailability of $\mathrm{Pb}$, As and Cs in Mississippi River Delta paddy soil under an electrokinetic field (EKF). Effects of EKF on soil $\mathrm{pH}$ changes and solid-phase distributions of metal(loid)s were examined. Results showed that fractionation of $\mathrm{Pb}$, As and Cs was largely determined by the nature of elements, loading levels and EKF treatment. Native $\mathrm{Pb}$ in the soil was mostly in the amorphous iron oxide, organic matter and residual fractions, native As in the amorphous iron oxide, easily reducible oxide and residue fractions while native $\mathrm{Cs}$ in the residue fraction. Added $\mathrm{Pb}$, As and Cs showed distinguished solid-phase distributions: $\mathrm{Pb}$ dominantly in the organic matter fraction; As in the amorphous iron oxide fraction, and $\mathrm{Cs}$ in the residue with a significant watersoluble plus exchangeable fraction. EKF treatment is effective on lowering soil $\mathrm{pH}$ to 1.5 near the anode due to water electrolysis releasing proton which is beneficial for dissolution of metal(loid)s, increasing their overall solubility. The acidification in the anode soil efficiently increased the water-soluble $\mathrm{Pb}$ and the exchangeable $\mathrm{Cs}$, implying enhanced solubility and elevated their overall potential bioavailability in the anode region while lower solubility in the cathode area. The building up of watersoluble As in the anode region may be from electromigration of As anion from the cathode. This study shows
\end{abstract}

$\triangle$ F. X. Han

Fengxiang.han@jsums.edu

1 College of Water Conservancy and Hydropower Engineering, Hohai University, Nanjing 210098, China

2 Department of Chemistry and Biochemistry, Jackson State University, 1400 J. R. Lynch Street, P. O. Box 17910, Jackson, MS 39217, USA significant enhancement of redistribution, elevated solubility and overall bioavailability of $\mathrm{Pb}, \mathrm{As}$ and $\mathrm{Cs}$ in Mississippi Delta paddy soil under the EKF.

Keywords Metal(loid) - Distribution · Mobility · Bioavailability $\cdot$ Electrokinetic remediation

\section{Introduction}

Soil pollution with heavy metal(loid)s is an increasing global concern due to their persistence, high toxicity and potential carcinogenic characteristics (Davies 1980; Kabata-Pendias 2000; Adriano 2001; Han et al. 2007). Heavy metal(loid)s such as lead (Pb) and arsenic (As) are mainly released to soils from anthropogenic activities such as industrial, agricultural and mining activities (Davies 1980; Kabata-Pendias 2000; Adriano 2001; Cameselle et al. 2013). It was suggested that top soil could be a permanent sink for anthropogenic $\mathrm{Pb}$ and $\mathrm{As}$ compounds from the atmosphere or hydrosphere (Salazar and Pignata 2014). Pb was largely released to the environment due to coal burning dating from the industrial revolution (Davies 1980; Kabata-Pendias 2000; Adriano 2001; Shotyk et al. 1997). The introduction and combustion of leaded gasoline peaked the $\mathrm{Pb}$ emission to the environment during the 1950s-1980s. It was reported that the highest content of $\mathrm{Pb}$ was up to $209 \mathrm{mg} \mathrm{kg}^{-1}$ in the top roadside soils (Banin et al. 1987). Arsenic is primarily derived from sulfide mining (as $\mathrm{As}^{5+}$ in most minerals), tailings (both fully oxidizing tailing with $\mathrm{As}^{5+}$ adsorbed on $\mathrm{Fe}$ oxides and partially oxidizing tailings with $20 \%$ arsenopyrite, FeAsS and $80 \% \mathrm{As}^{5+}$ scorodite, $\mathrm{FeAsO}_{4} \cdot 2 \mathrm{H}_{2} \mathrm{O}$ ), industrial activities such as electronic, fireworks ceramics and glass (Porter and Peterson 
1977; Foster et al. 1998). During the twentieth century, widespread soil pollution with As has been resulted from indiscriminate use of pesticides, herbicides, desiccants and fertilizers in agricultural activities (Mandal 2002). Soils in contaminated sites have been detected with As content as high as more than $1000 \mathrm{mg} \mathrm{kg}^{-1}$ (Smith et al. 1998).

On the other hand, as a radionuclide, cesium has been released into soils through nuclear wastes, nuclear power plant accidents, and nuclear weapon testing (Giannakopoulou et al. 2007). 137Cs is a radionuclide of great concern with a half-life of 30.2 years due to its high bioavailability and chemical and biological similarity with potassium, an essential element in living organisms. Chernobyl accident released a huge amount of 137Cs and other radionuclides into surrounding soils (Belarus, Ukraine and Russia) and even spread through the entire Northern Hemisphere (Gommers et al. 2005; Kashparov et al. 2005). Similarly, radionuclides $134 \mathrm{Cs}$ and $137 \mathrm{Cs}$ ) were released during the Fukushima Daiichi nuclear power plant accident in 2011. 137Cs has heavily contaminated the soils in large areas of eastern and northeastern Japan (Yasunari et al. 2011). The soils around Fukushima and neighboring prefectures have been extensively contaminated with depositions of 137Cs in Japan Islands and the surrounding ocean (Yasunari et al. 2011). Radionuclides were reported to be also present and be transported in colloids of groundwater of nuclear ground detonation sites such as the Nevada Test Site (Kersting et al. 1999; Yasunari et al. 2011).

Some current practices for remediating heavy metal(loid)-contaminated soils relies on "dig-and-dump" or encapsulation, neither of which addresses the issue of soil decontamination. Immobilization or extraction by physicochemical techniques may be expensive and are often appropriate only for small areas where rapid and complete decontamination is required. Other remediation methods, such as soil washing, have an adverse effect on biological activity, soil structure and fertility in addition to significant engineering costs (Pulford and Watson 2003). On the other hand, phytoremediation is an emerging technology that uses various plants to degrade, extract, contain or immobilize contaminants from soil and water (Raskin and Ensley 2000). Phytoextraction is the process of concentrating metals/metalloids in the stems and leaves of accumulating plants (Raskin and Ensley 2000). The development of phytoremediation is being driven primarily due to the high cost of other soil remediation methods as well as the desire to use an environmental benign process. Potential obstacles to a large-scale application of phytoremediation technologies include the time period required for remediation, pollutant levels tolerated by plants and the relative low bioavailability of contaminants.

The water-soluble and exchangeable fractions of metal(loid)s, which are in equilibrium with the solidphase speciation, are the most bioavailable form to plants (Han et al. 2007; Adriano 2001). The metals and metalloids are present in many solid-phase fractions including exchangeable, carbonate bound, organic bound, iron/manganese oxide bound etc. (Tessier et al. 1979; Han et al. 2007; Han and Banin 1997, 1999; Han et al. 2006, 2008, Han et al. 2012). In order to improve the mobility and bioavailability of heavy metal(loid) in soil, electrokinetic field (EKF) was introduced to enhance phytoremediation efficiency of metal(loid) contaminated soils (Cameselle et al. 2013). EKF involves using a direct or alternating current with electrodes inserted into contaminated soils. When a low intensity electric field is applied, $\mathrm{H}^{+}$is generated around the anode electrode through the effect of water electrolysis. As a result, more metal(loid)s are demobilized under the acid condition around the anode electrode (Thangavel 2004). In addition, enhanced mobilization processes occur in soils resulting in the transport of metal(loid) ions from the anode to the cathode electrode (Dermont et al. 2008). Electromigration and electroosmosis are two main mechanisms for metal/metalloid transportation (Fig. 1). Water present in soil is able to move toward the cathode through soil pores by electroosmosis, while cations could move to the cathode through electromigration (Cameselle and Reddy 2012). The migration of ions makes it possible for the subsequent removal of soluble metal(loid)s or immobilization with oxides, hydroxides and carbonates during the phytoremediation (Ottosen et al. 2007). However, the detailed mechanisms of releasing/mobilization of metals/metalloids with EKF through transformation of metal/metalloids among various solid-phase components were not clearly understood.

The objectives of this study were: (1) to investigate the fractionation and distribution of $\mathrm{Pb}$, As and $\mathrm{Cs}$ among solid-phase components in Mississippi River Delta paddy soil with different input levels, (2) to investigate changes of soil $\mathrm{pH}$ influenced by EKF, (3) to determine the redistribution/transformation processes of $\mathrm{Pb}$, As and $\mathrm{Cs}$ in soils under EKF from stable fractions into labile fractions, and (4) to evaluate the solubility and overall potential bioavailability of $\mathrm{Pb}, \mathrm{As}$ and $\mathrm{Cs}$ under constant electrical parameters of EKF such as electrical field intensity, mode of voltage, operational time and the distance between the anode and cathode electrodes. 


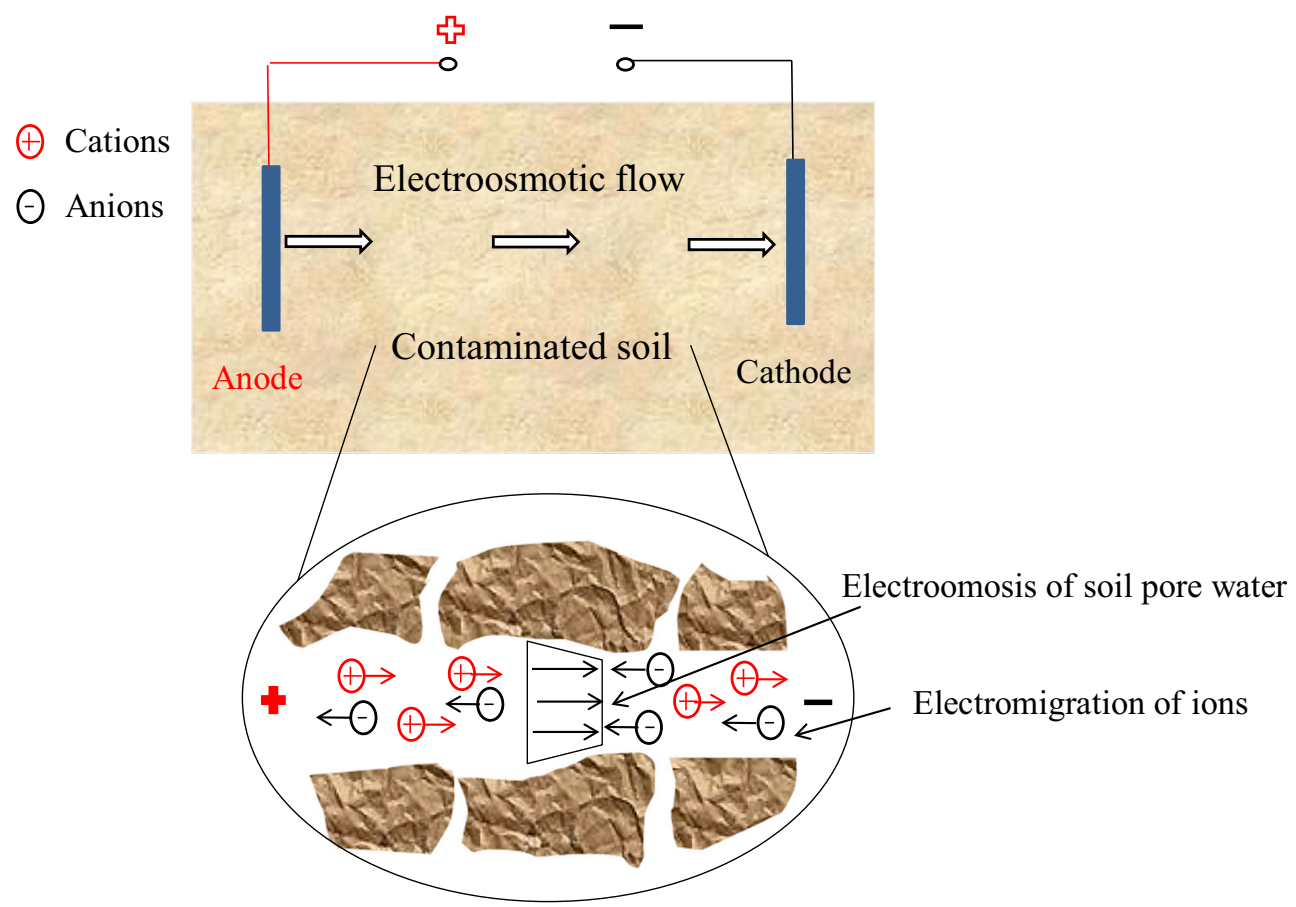

Fig. 1 Diagram of electrokinetic remediation (EKR) of metal(loid) contaminated soils under electrokinetic field (EKF)

\section{Materials and methods}

\section{Soil and experimental design}

A surface paddy soil $(0-15 \mathrm{~cm})$ was sampled from the rice field in the MS River Delta. All soil samples were air-dried and ground to pass $2 \mathrm{~mm}$ sieve. Two replicates were set for each treatment (Table 1). About $1 \mathrm{~kg}$ of air-dried soil was weighed and placed into each plastic pot with 6 in. $(15.2 \mathrm{~cm})$ diameter and $5.4(13.7 \mathrm{~cm})$ inch height. Chemical grade lead nitrate $\left(\mathrm{Pb}\left(\mathrm{NO}_{3}\right)_{2}\right)$, sodium arsenite $\left(\mathrm{NaAsO}_{2}\right)$ and cesium chloride $(\mathrm{CsCl})$ were used as $\mathrm{Pb}, \mathrm{As}$ and $\mathrm{Cs}$ sources, respectively. Three content levels were applied for each metal(loid). $\mathrm{Pb}$ treatments included the control, 200, 600 and $1000 \mathrm{mg} \mathrm{kg}^{-1}$; As treatments were control, 5, 20 and $100 \mathrm{mg} \mathrm{kg}^{-1}$; and Cs treatments

Table 1 Experimental design of metal(loid) treatments with and without electrokinetic field (EKF)

\begin{tabular}{lrrr}
\hline Treatment & \multicolumn{2}{c}{ Addition of heavy metal(loid)s $\left(\mathrm{mg} \mathrm{kg}^{-1}\right)$} & \\
\cline { 2 - 4 } & $\mathrm{Pb}$ & 0 & $\mathrm{Cs}$ \\
\hline Without EKF & 0 & 20 & 0 \\
& 600 & 100 & 20 \\
With EKF & 1000 & 20 & 100 \\
\hline
\end{tabular}

included the control, 5, 20 and $100 \mathrm{mg} \mathrm{kg}^{-1}$. The control and the middle level treatments for each element were selected for application of EKF: Pb $\left(600 \mathrm{mg} \mathrm{kg}^{-1}\right)$, As $\left(20 \mathrm{mg} \mathrm{kg}^{-1}\right)$ and $\mathrm{Cs}\left(20 \mathrm{mg} \mathrm{kg}^{-1}\right) . \mathrm{Pb}$, As and Cs salts were ground and mixed with air-dried soil to ensure the homogeneity of mixing the salts with soil. Water moisture was kept at field capacity throughout the incubation period.

\section{EKR setup and determination of metal(loid) speciation}

A DC power supplier $(0-60 \mathrm{~V}, 0-3 \mathrm{~A})$ was used as an electrical power source. Graphite electrode rods $(0.95 \mathrm{~cm}$ diameter, $30.5 \mathrm{~cm}$ length) were used as both anodes and cathodes due to their low cost and inertness. A DC electrical field with a constant intensity of $1 \mathrm{~V} \mathrm{~cm}^{-1}$ was applied to soil in plastic pots with a medium concentration level of $\mathrm{Pb}$, As and $\mathrm{Cs}$ treatments, respectively. A pair of graphite electrode rods was vertically inserted into both sides of each pot with $13 \mathrm{~cm}$ below the soil surface. The copper wire was used to connect the electrode rods with the power source. The electrical equipments were set up after 5 weeks of equilibrium of elements added in soil. In order to study the soil $\mathrm{pH}$ and metal(loid) distribution, mobility and bioavailability, the direct current electrical field was applied for $24 \mathrm{~h}$ a day. After 15 days of field EKF treatment, surface soil samples $(0-5 \mathrm{~cm})$ were collected in the 
anode, the middle and the cathode regions of each pot, respectively. The speciation and solid-phase fractionation of metal(loid)s influenced under EKR were examined.

\section{Determination of soil $\mathrm{pHs}$}

About $10 \mathrm{~g}$ of soil sample was mixed with deionized water at a soil/water ratio of 1:1. Stir the mixture vigorously and allow the slurry to set for about $15 \mathrm{~min}$. A pH meter was used to measure the $\mathrm{pH}$ of the slurry after calibration using $\mathrm{pH} \mathrm{4,} 7$ and 10 buffer solutions. The electrode of the $\mathrm{pH}$ meter was directly placed into soil slurry, and then $\mathrm{pH}$ was read and recorded. Room temperature $\left(20-25{ }^{\circ} \mathrm{C}\right)$ was ensured throughout the $\mathrm{pH}$ measurement.

\section{Metal(loid) fractionation and chemical analysis}

Lead, arsenic and cesium were assumed to be presented in seven operationally defined fractions (as water-soluble, exchangeable, easily reducible oxide bound, organic matter bound, amorphous iron oxide bound, crystalline iron oxide bound and residual fractions) in soils and obtained with selective sequential dissolution (SSD) which was developed based on sequential extraction procedure proposed by Tessier et al. (1979) and Han and Banin (1997).

\section{Water soluble (SOL)}

$1.2 \mathrm{~g}$ air-dried soil and $25 \mathrm{~mL}$ of $0.01 \mathrm{M} \mathrm{CaCl}_{2}$ were added into a $50-\mathrm{mL}$ Teflon centrifuge tube. The mixture were shaken for $30 \mathrm{~min}$ at room temperature and then centrifuged for $10 \mathrm{~min}$ at $6000 \mathrm{rpm}$. The supernatant was filtrated through a $0.45-\mu \mathrm{m}$ filter and kept for the analysis. The soil residue was kept in the Teflon tube for the next extraction procedure. The same centrifugation operation was applied in the following six extraction steps.

\section{Exchangeable (EXC)}

Soil residue from the water-soluble fraction was extracted with $25 \mathrm{~mL}$ of $1 \mathrm{M}$ neutral $\mathrm{NH}_{4} \mathrm{NO}_{3}$. The mixture was shaken for $30 \mathrm{~min}$ at room temperature.

\section{Easily reducible oxide bound (ERO)}

Soil residue was mixed with $25 \mathrm{~mL}$ of $0.1 \mathrm{M} \mathrm{NH} \mathrm{NH}_{2}$ OH.HCL $+0.01 \mathrm{M} \mathrm{HCl}$ and shaken for $30 \mathrm{~min}$.

\section{Organic matter bound (OM)}

Soil residue was first mixed with $3 \mathrm{~mL}$ of $0.01 \mathrm{M} \mathrm{HNO}_{3}$ and $5 \mathrm{~mL}$ of $30 \% \mathrm{H}_{2} \mathrm{O}_{2}$. Then, after digestion in water bath for $2 \mathrm{~h}$ at $80{ }^{\circ} \mathrm{C}$, another $2 \mathrm{~mL}$ of $30 \% \mathrm{H}_{2} \mathrm{O}_{2}$ was added. After $1 \mathrm{~h}$ heating, $15 \mathrm{~mL}$ of $1 \mathrm{M} \mathrm{NH}_{4} \mathrm{NO}_{3}$ was added and the mixture was agitated for $10 \mathrm{~min}$.

Amorphous iron oxide bound (AmoFe)

Soil residue was extracted with $25 \mathrm{~mL}$ of $0.2 \mathrm{M}\left(\mathrm{NH}_{4}\right)_{2-}$ $\mathrm{C}_{2} \mathrm{O}_{4}-\mathrm{H}_{2} \mathrm{C}_{2} \mathrm{O}_{4}$, and the mixture was shaken for $4 \mathrm{~h}$ in the dark environment.

\section{Crystalline iron oxide bound (CryFe)}

Soil residue was added with $25 \mathrm{~mL}$ of $0.04 \mathrm{M} \mathrm{NH}_{2} \mathrm{OH} \cdot \mathrm{HCl}$ and $25 \% \mathrm{CH}_{3} \mathrm{COOH}$. The mixture was then digested in water bath for $3 \mathrm{~h}$ at $95{ }^{\circ} \mathrm{C}$.

\section{Residue (RES)}

Soil residue was added with $25 \mathrm{~mL}$ of $4 \mathrm{M} \mathrm{HNO}_{3}$ and digested in water bath for $16 \mathrm{~h}$ at $80{ }^{\circ} \mathrm{C}$.

Supernatants collected after centrifugation were filtrated through $0.45 \mathrm{~mm}$ filter and further diluted for 20 folds. $\mathrm{Pb}$, As and Cs concentrations in supernatants were determined with inductively coupled plasma mass spectrometry (ICPMS).

\section{Statistical analysis}

The data were processed and the average and the standard deviations were calculated with Microsoft Excel. SPSS 11.5 software was used for statistical analyses. Duncan's multiple range tests were applied for significant analysis of $\mathrm{pH}$ changes and metal(loid) speciation under EKF $(P<0.05)$.

\section{Results and discussion}

\section{Distribution of $\mathrm{Pb}, \mathrm{As}$ and $\mathrm{Cs}$ in soils with various loading levels}

The distribution of $\mathrm{Pb}$, As and $\mathrm{Cs}$ among various solidphase fractions in soils depended upon the nature of elements and their loading levels (Fig. 2). In general, $\mathrm{Pb}$, As and Cs in contaminated soils showed distinguished solidphase distributions: $\mathrm{Pb}$ was dominantly presented in the OM bound fraction (38-52\%); As mainly in the AmoFe bound fraction (40-46\%); and Cs dominantly in the RES fraction $(62-68 \%)$ and SOL + EXC (10-17\%). The native $\mathrm{Pb}$, As and $\mathrm{Cs}$ in soils showed similar distributions: $\mathrm{Pb}$ was dominantly bound to the AmoFe fraction (35\%), followed by the OM fraction $(28 \%)$ and RES fraction (18\%); As mainly bound to the AmoFe fraction (57\%), followed by the ERO (14\%) and RES fractions (12\%); 

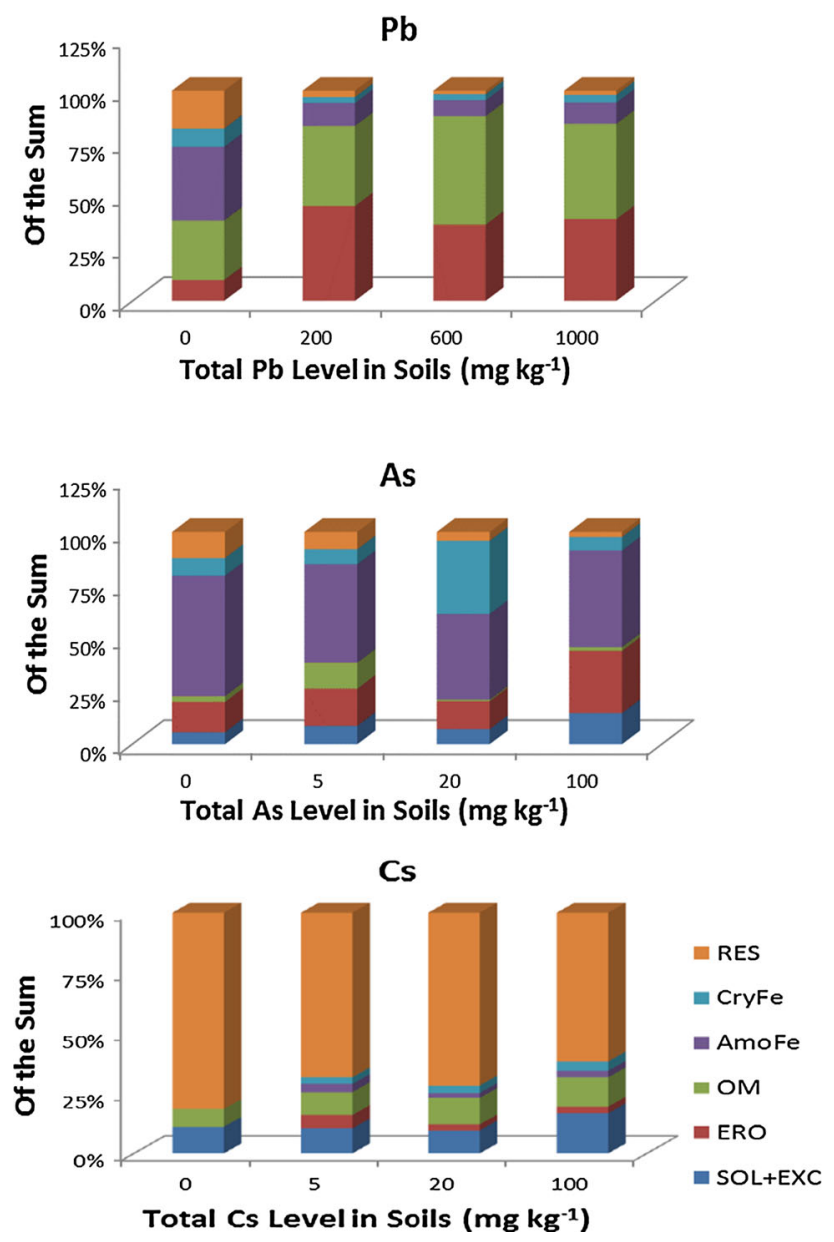

Fig. 2 Distribution of $\mathrm{Pb}$, As and Cs among solid-phase components in Mississippi Delta paddy soils as the increase in $\mathrm{Pb}$, As and $\mathrm{Cs}$ loading levels (Day 2 incubation)

and Cs dominantly in the RES fraction ( $81 \%$ ), followed by the SOL + EXC (11\%) and OM bound fractions (7\%).

Obviously, distributions of $\mathrm{Pb}$, As and $\mathrm{Cs}$ in soils were significantly influenced by loading levels (Figs. 2, 3). $\mathrm{Pb}$ in the OM and ERO fractions, As in the AmoFe and ERO fractions, and Cs in the RES and SOL + EXC fractions all linearly increased with their loading levels. All other solidphase fractions slowly increased with the loading level as well. This indicates that the organic matter $(\mathrm{OM})$ and $\mathrm{Mn}$ oxides (ERO fraction) were major solid-phase components for binding added $\mathrm{Pb}$, the amorphous iron oxides (AmoFe) and $\mathrm{Mn}$ oxides (ERO) for added As, and surface exchangeable sites on clay and oxide mineral surfaces (the RES and SOL + EXC fractions) for added Cs. Since Mn/ Fe oxides are surface susceptible to redox potential as a change of water regime (Han and Banin 1996), the decrease in redox potential in soil may result in the increase in $\mathrm{As}$ and $\mathrm{Pb}$ bioavailability. Cesium is
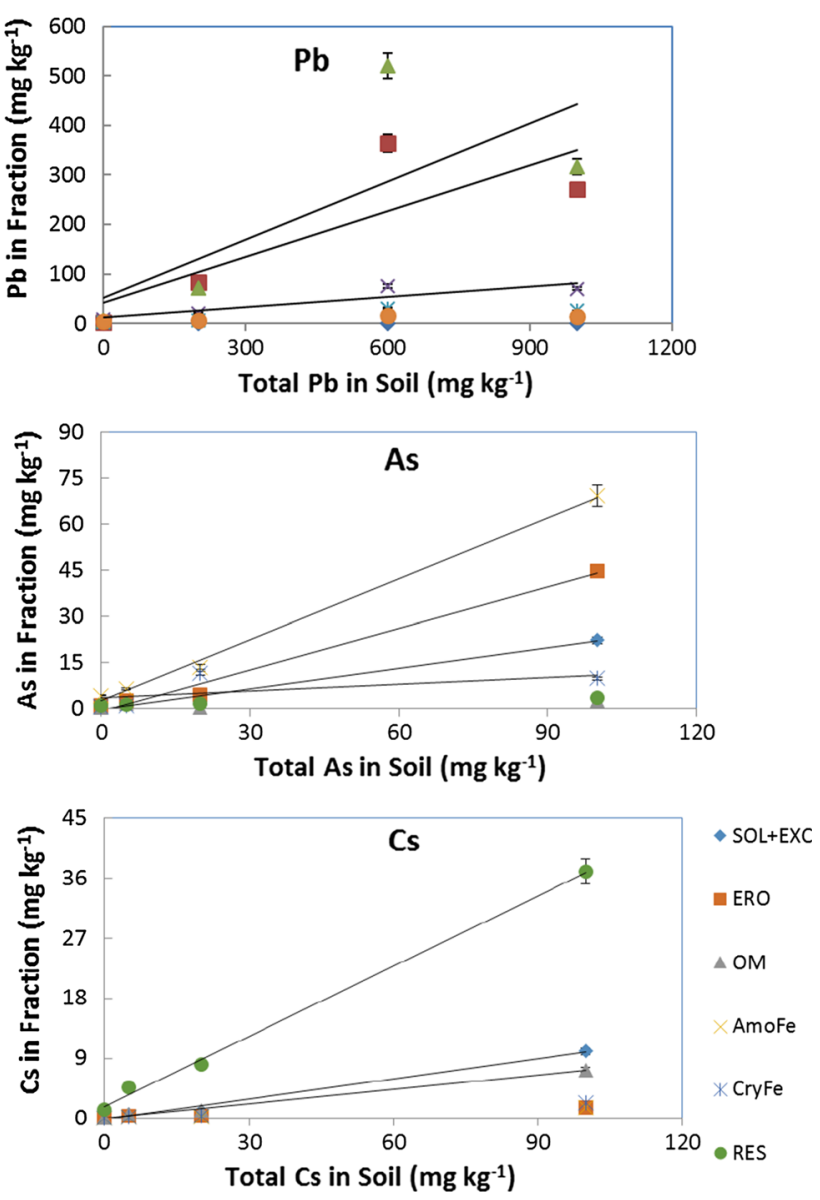

Fig. 3 The increases in concentrations of $\mathrm{Pb}, \mathrm{As}$ and $\mathrm{Cs}$ in solidphase fractions with total $\mathrm{Pb}$, As and $\mathrm{Cs}$ loading levels (Day 2 incubation)

significantly presented in the water-soluble and surface exchangeable fractions, possessing a high solubility and potential bioavailability.

It was reported that distribution of heavy metal(loid)s in soils depended on the nature of elements and their total content (Han et al. 2007). In addition, soil physicochemical properties such as $\mathrm{pH}$, redox potential and organic matter content also influence speciation and binding in soils (Han and Banin 1997; Nyamangara 1998). It was suggested that the water-soluble and exchangeable fraction of metal(loid)s were used to estimate their mobility and bioavailability to plants (Adriano 2001; Kabata-Pendias 2000). Based on the general distribution of metals/metalloids in soil solid components, trace elements are divided into three categories according to their phytoavailability: readily bioavailable $(\mathrm{Cd}, \mathrm{Ni}, \mathrm{Zn}, \mathrm{As}, \mathrm{Se}, \mathrm{Cu})$; moderately bioavailable ( $\mathrm{Co}, \mathrm{Mn}, \mathrm{Fe})$ and least bioavailable $(\mathrm{Pb}, \mathrm{Cr}, \mathrm{U}$; Prasad 2003). $\mathrm{Pb}$ and $\mathrm{As}$ are the two most widespread contaminants in soils. It was reported that exogenous $\mathrm{Pb}$ in 
agricultural soils was dominantly present in the RES fraction, followed by the OM bound and ERO bound fractions indicating the low bioavailability of $\mathrm{Pb}$ (Huang et al. 2014). Arsenic in poultry waste-amended Mississippian soil was mainly present in the RES and $\mathrm{Mn} / \mathrm{Fe}$ oxide bound fractions (Han et al. 2004a, b). However, arsenic in mined soils was dominantly present in the AmoFe fraction, followed by the CryFe and ERO fractions and a significant increase in the SOL and EXC fractions was observed as the increase in As addition (Marabottini et al. 2013). Not many studies were reported on the distribution of Cs in contaminated soils.

\section{Effect of the electrokinetic field (EKF) on soil pHs}

The changes of soil pHs under EKF are shown in Fig. 4. Medium concentration level of $\mathrm{Pb}\left(600 \mathrm{mg} \mathrm{kg}^{-1}\right)$, As $\left(20 \mathrm{mg} \mathrm{kg}^{-1}\right)$ and $\mathrm{Cs}\left(20 \mathrm{mg} \mathrm{kg}^{-1}\right)$ were used for EKF treatment, respectively. The $\mathrm{pHs}$ of different metal(loid) contaminated soils without EKF were all around 6.7, while pHs in the control soil without metal(loid) were around 7.49. This suggested that distribution of metal(loid)s in MS River Delta paddy field soil reduced soil $\mathrm{pH}$. With enhancement of $\mathrm{EKF}$, the pHs of treated soils were significantly polarized upon the electricity current. Sub-region soils near the anode and cathode areas for $\mathrm{Pb}-$, As- and Cs-treated soils were around 1.5 and 10.8, respectively, which significantly changed compared to those without EKF. The data indicated significant acidification and alkalization under operational electrical conditions at DC electrical field intensity of $1 \mathrm{~V} \mathrm{~cm}^{-1}$ for a period of 15 days $(24 \mathrm{~h}$ a day). It was resulted from the electrolysis of water releasing proton $\left(2 \mathrm{H}_{2} \mathrm{O} \rightarrow \mathrm{O}_{2} \quad(\mathrm{~g})+4 \mathrm{H}^{+}+4 \mathrm{e}\right.$ at the anode; $4 \mathrm{H}_{2} \mathrm{O}$ $+4 \mathrm{e} \rightarrow 2 \mathrm{H}_{2}(\mathrm{~g})+4 \mathrm{OH}^{-}$at the cathode) during the EKF. Furthermore, the pHs of soils in the middle region (around 7.5) were larger than those without EKF (around 6.7) indicating the migration of $\mathrm{OH}^{-}$from the cathode to the anode.

Since most metal(loid)s are solubilized in acid soil environment, lowering soil $\mathrm{pH}$ becomes a strategy for increasing bioavailability of most metal(loid)s in soils. Strong acids and weak acids are usually used to neutralize the $\mathrm{OH}^{-}$in soils with high acid/base buffer capacity (Pérez-Esteban et al. 2013). However, potential risks may be generated in the acidification process. It was reported that, lowering soil $\mathrm{pH}$ with $\mathrm{HCl}$ may increase the leaching potential of metals and $\mathrm{Cl}^{-}$to groundwater and the formation of some insoluble salts (i.e., $\mathrm{PbCl}_{2}$; Yeung and $\mathrm{Gu}$ 2011). Weak acid such as citric acid and acetic acid are environmental friendly and biodegradable, while their effect on lowering soil $\mathrm{pH}$ is not as effective as strong acid (Yeung and Gu 2012). As supported by the present study,
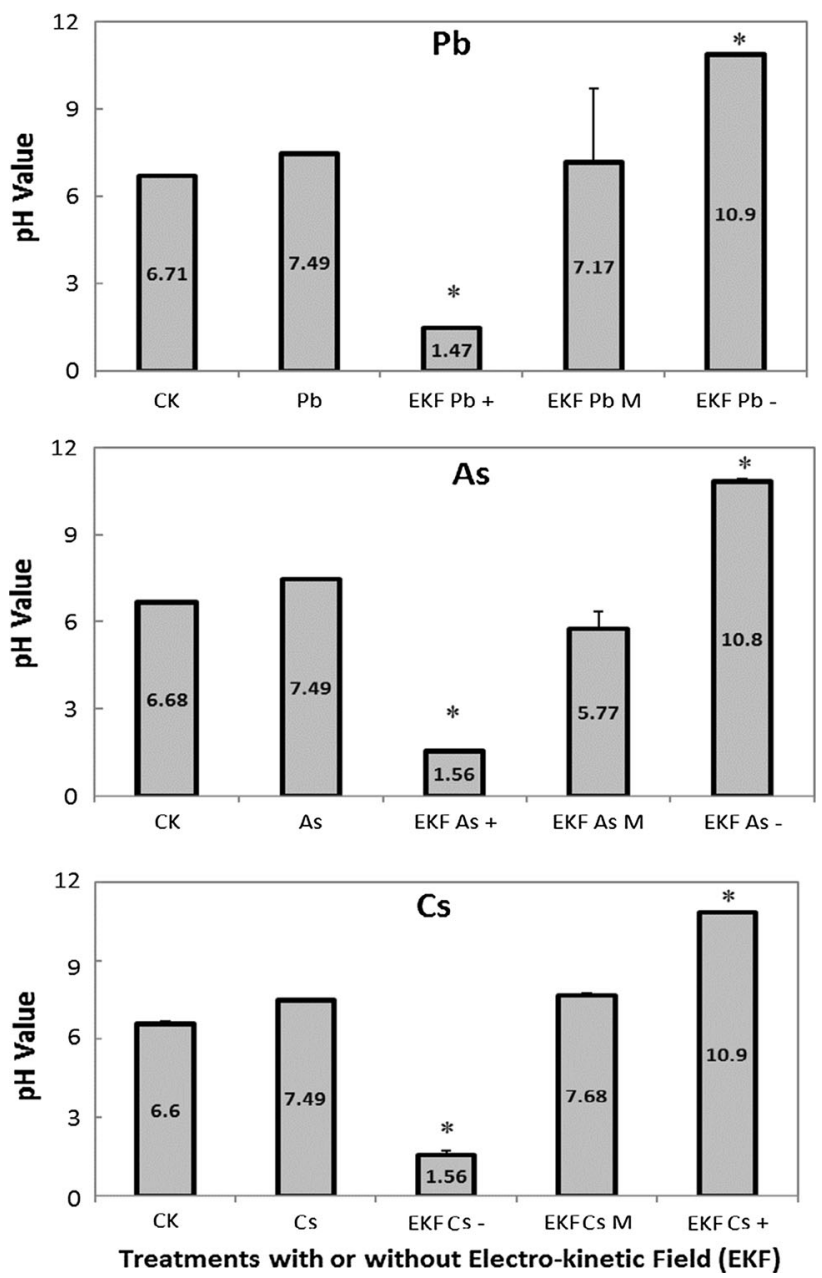

Fig. 4 Effects of EKF on $\mathrm{pH}$ changes of $\mathrm{Pb}-$, As-, and Cscontaminated soil in the anode $(+)$, cathode $(-)$, the middle region (M) between two electrodes, the control soil (CK) and the polluted soils without EKF ( $\mathrm{Pb}, \mathrm{As}, \mathrm{Cs})$. Soil was contaminated with $600 \mathrm{mg} \mathrm{kg}^{-1} \mathrm{~Pb}, 20 \mathrm{mg} \mathrm{kg}^{-1}$ As and $20 \mathrm{mg} \mathrm{kg}^{-1}$ Cs. Means followed by the asterisk were significantly different compared with the control soil $(\mathrm{CK})$ at $P<0.05$

EKF seemed an effective technique to lower soil $\mathrm{pH}$ (Puppala et al. 1997). $\mathrm{H}^{+}$generated by the electrolysis of water decreased the soil $\mathrm{pH}$ near the anode region. Through electromigration and electroosmosis, $\mathrm{H}^{+}$could be transported toward the cathode and naturalize generated $\mathrm{OH}^{-}$ ions to some extent (Kim et al. 2010). Acidification of soil $\mathrm{pH}$ was beneficial for solubilization and removal of metal(loid)s such as $\mathrm{Pb}, \mathrm{Cr}, \mathrm{Cd}, \mathrm{Cu}$ and $\mathrm{Zn}$ (Altin and Degirmenci 2005; Iannelli et al. 2015; Lu et al. 2012; Virkutyte et al. 2002). In addition, addition of organic acids may neutralize the $\mathrm{OH}^{-}$to some extent and avoided the precipitation of metal(loid)s in the vicinity of the cathode (Lee and Yang 2000; Saichek and Reddy 2003). 
$\mathrm{Pb}$

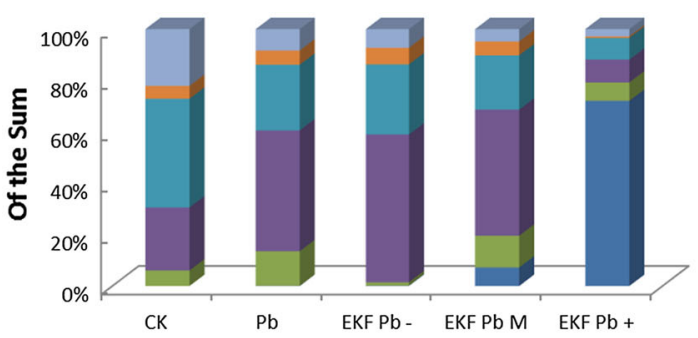

As
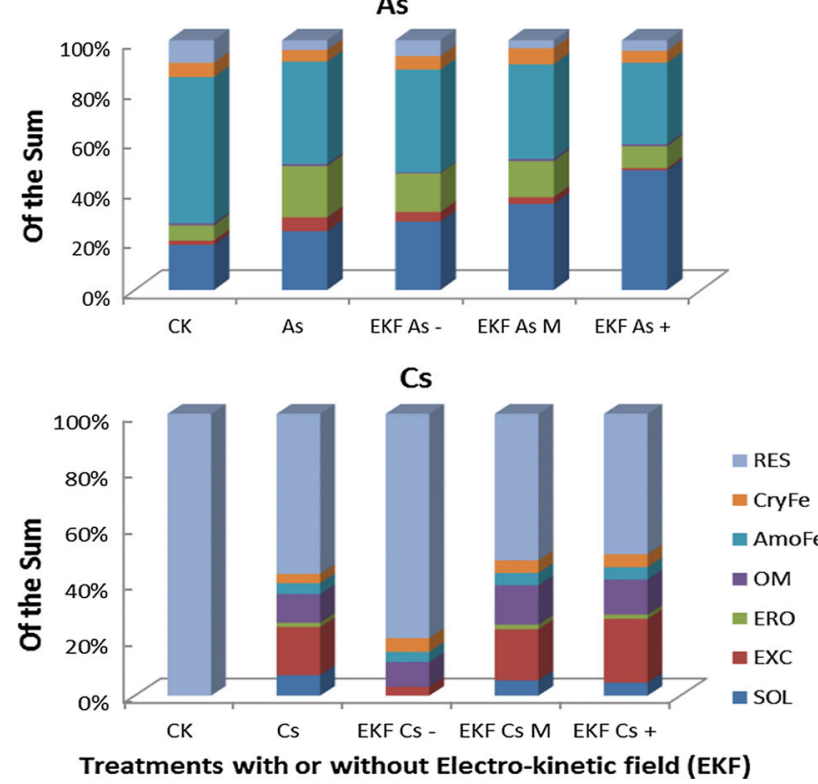

Fig. 5 Distribution of $\mathrm{Pb}$, As and $\mathrm{Cs}$ among solid-phase components in contaminated soil with EKF in the anode $(+)$, cathode $(-)$, the middle region $(\mathrm{M})$ between two electrodes, the control soil $(\mathrm{CK})$ and the polluted soils without EKF ( $\mathrm{Pb}, \mathrm{As}, \mathrm{Cs})$. Soil was contaminated with $600 \mathrm{mg} \mathrm{kg}^{-1} \mathrm{~Pb}, 20 \mathrm{mg} \mathrm{kg}^{-1}$ As and $20 \mathrm{mg} \mathrm{kg}^{-1} \mathrm{Cs}$

\section{Distribution of $\mathrm{Pb}, \mathrm{As}$ and $\mathrm{Cs}$ among solid-phase fractions with EKF treatment}

The distribution of $\mathrm{Pb}, \mathrm{As}$ and $\mathrm{Cs}$ among solid-phase components under EKF are shown in Fig. 5. With enhancement of $\mathrm{EKF}$, distributions of $\mathrm{Pb}$, As and $\mathrm{Cs}$ in soils were dramatically changed. Generally, the native $\mathrm{Pb}$ was mainly present in the AmoFe and $\mathrm{OM}$ fractions while added $\mathrm{Pb}$ at $600 \mathrm{mg} \mathrm{kg}^{-1}$ was mainly in the $\mathrm{OM}$, followed by AmoFe and ERO fractions. With EKF, $\mathrm{Pb}$ in soil near the cathode and the middle regions was similar to the treated $\mathrm{Pb}$ without $\mathrm{EKF}$, but $\mathrm{Pb}$ in the soil near to the anode was dominantly in the water-soluble (SOL) form. $\mathrm{Pb}$ in the SOL fraction increased from the soil near the cathode, to the middle region, to the soil near to the anode due to the acidification. The $\mathrm{OM}$ bound fraction of $\mathrm{Pb}$ decreased from the soil in the cathode $(57 \%)$ to that in the anode areas
(6.0\%). Same patterns were observed for $\mathrm{Pb}$ in the $\mathrm{AmoFe}$ (27-5.8 \%), CryFe (6.4-0.4\%) and RES (7.1-1.9\%) fractions. On the contrary, the SOL fraction was increased from $1.4 \%$ near the cathode to $86 \%$ near the anode indicating the large potential mobility and bioavailability of $\mathrm{Pb}$ enhanced with EKF.

The native and added As was mainly presented in the AmoFe and ERO fractions. With EKF, As in soils near to the cathode and the middle region was similar to As-treated soil without EKF. As in the AmoFe fraction decreased from the cathode $(54.7 \%)$, to the middle region (49\%) and to the anode region (46\%). However, the water-soluble As (SOL) in the anode increased to $20.7 \%$ while that in the cathode was $5.7 \%$.

The native and added Cs in soils was dominantly presented in the RES fraction with a significant amount in the EXC and OM fractions. With EKF, Cs in the EXC fraction increased from the soil near the cathode to the middle region, to the soil near the anode. A large decrease was shown in the RES fraction from the areas near the cathode $(82 \%)$ to the anode $(65 \%)$. Cs in the EXC fraction increased from the cathode $(0.36 \%)$, to the middle region $(2.8 \%)$ and to the anode region $(3.5 \%)$.

Distributions of $\mathrm{Pb}, \mathrm{As}$ and $\mathrm{Cs}$ in the anode region were more significantly affected than in cathode areas during the EKF. This was the result of strong acidification for solubilization of $\mathrm{Pb}$ and $\mathrm{Cs}$ around the anode as well as possible electromigration of As anion from the cathode where As was solubilized at high $\mathrm{pH}$. Basically, more water-soluble $\mathrm{Pb}$ and $\mathrm{As}$ (SOL) were presented in the soil near the anode, while more Cs was found in EXC fraction due to strong acidity. Since acid environment is more beneficial for the transformation of metal(loid)s from the stable forms to the labile forms, $\mathrm{Pb}, \mathrm{As}$ and $\mathrm{Cs}$ in the ERO bound, AmoFe bound and CryFe bound fractions in soils were transferred and redistributed to the SOL and EXC fractions. Furthermore, changes in the solid-phase distribution in soils near the anode were significant compared to those in the middle region and cathode areas, i.e., building up of water-soluble and exchangeable ions in the anode may potentially facilitate the transport of ions such as diffusion processes from the anode to the cathode based on electroosmosis and electromigration. However, the effect of ion transport/diffusion on metal(loid) distribution and alternations of parameters in EKF such as the application of AC electrical field and the distances between the electrodes required further investigation to ensure the homogeneous distribution of metal(loid)s in soil.

The SOL and EXC fractions of metals/metalloids in soil represent their mobility and bioavailability to plants. Obviously, concentrations of $\mathrm{Pb}$, As and $\mathrm{Cs}$ in $\mathrm{SOL}$ and 

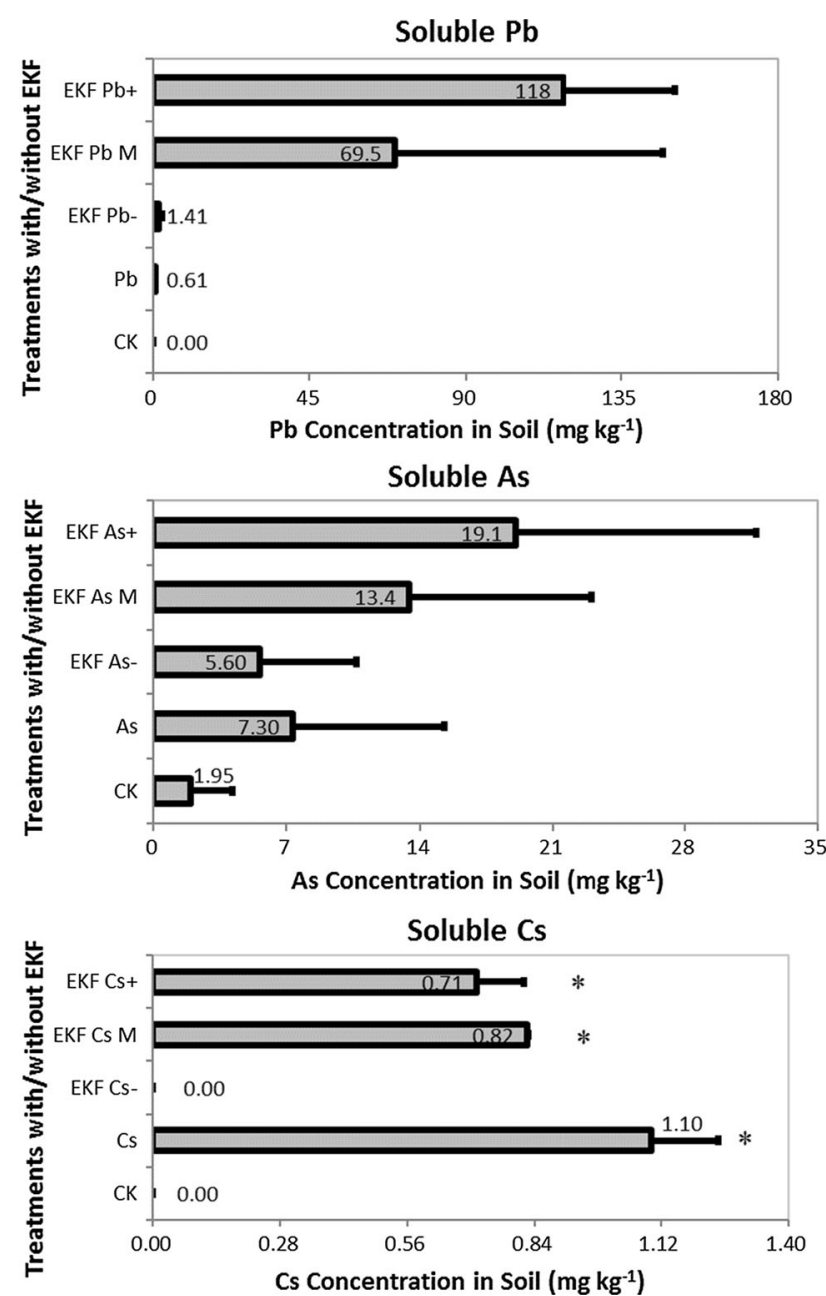

Fig. 6 Changes of soluble $\mathrm{Pb}, \mathrm{As}$ and $\mathrm{Cs}$ in soils with EKF in the anode $(+)$, cathode $(-)$, the middle region $(\mathrm{M})$ between two electrodes, the control soil (CK) and the polluted soils without EKF $\left(\mathrm{Pb}\right.$, As, Cs). Soil was contaminated with $600 \mathrm{mg} \mathrm{kg}^{-1} \mathrm{~Pb}$, $20 \mathrm{mg} \mathrm{kg}^{-1}$ As and $20 \mathrm{mg} \mathrm{kg}^{-1}$ Cs. Means followed by the asterisk were significantly different compared with the control soil (CK) at $P<0.05$

EXC fractions were strongly affected by EKF (Figs. 6, 7). At $\mathrm{Pb}$ addition of $600 \mathrm{mg} \mathrm{kg}^{-1}$, the $\mathrm{SOL}$ fraction of $\mathrm{Pb}$ in soil increased from $1.41 \mathrm{mg} \mathrm{kg}^{-1}$ near the cathode, to $69.46 \mathrm{mg} \mathrm{kg}^{-1}$ near the middle region and $118 \mathrm{mg} \mathrm{kg}^{-1}$ near the anode. Slight increase in the EXC fraction was shown $\left(0.05 \mathrm{mg} \mathrm{kg}^{-1}\right.$ increase $)$ in the anode area. It was suggested that the native $\mathrm{Pb}$ in soil usually is not bioavailable for phytoextraction. However, $\mathrm{Pb}$ tends to transfer to the SOL fraction under EKF. With As addition of $20 \mathrm{mg} \mathrm{kg}^{-1}$, the SOL fraction of As in soil increased from $5.6 \mathrm{mg} \mathrm{kg}^{-1}$ near the cathode, to $13.4 \mathrm{mg} \mathrm{kg}^{-1}$ near the middle region and $19.1 \mathrm{mg} \mathrm{kg}^{-1}$ near the anode, while
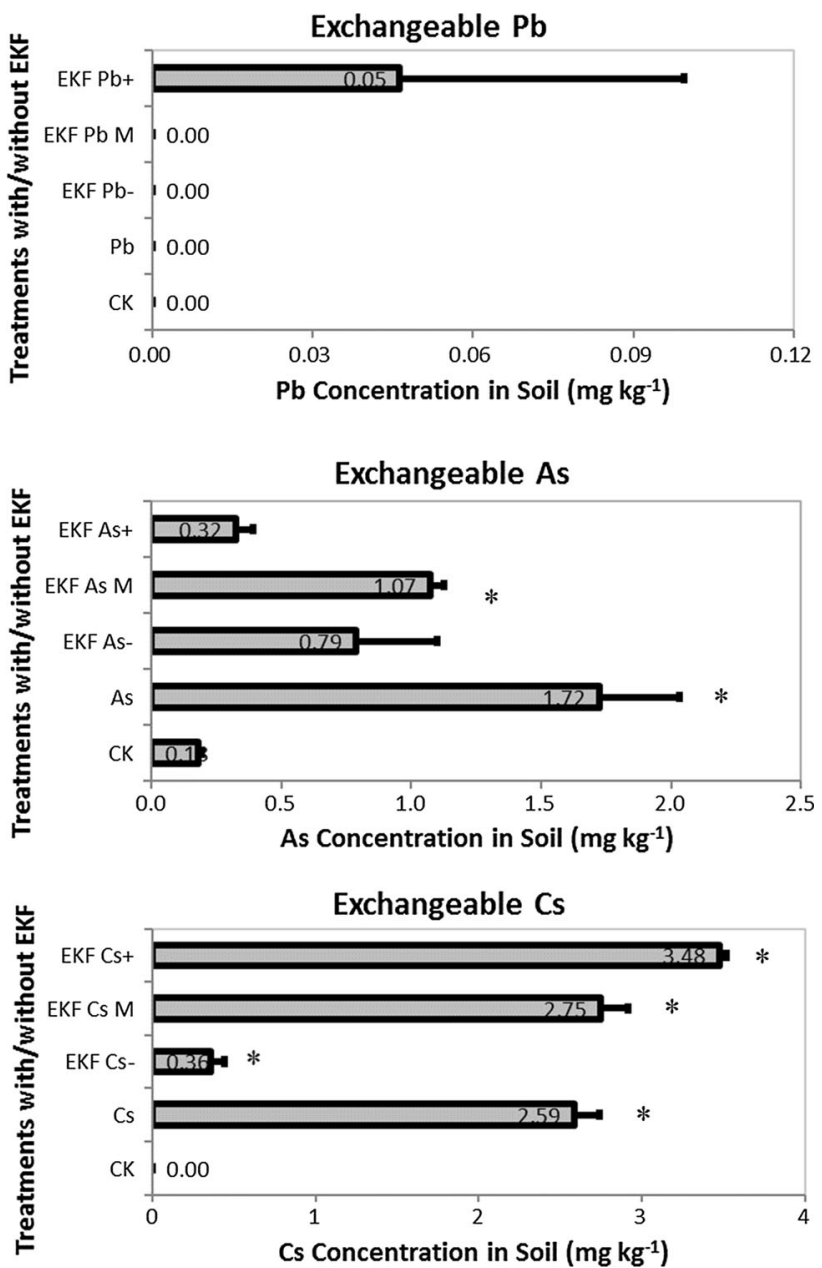

Fig. 7 Changes of exchangeable $\mathrm{Pb}$, As and $\mathrm{Cs}$ in soils with EKF in the anode $(+)$, cathode $(-)$, the middle region $(\mathrm{M})$ between two electrodes, the control soil (CK) and the polluted soils without EKF $(\mathrm{Pb}, \mathrm{As}, \mathrm{Cs})$. Soil was contaminated with $600 \mathrm{mg} \mathrm{kg}^{-1} \mathrm{~Pb}$, $20 \mathrm{mg} \mathrm{kg}^{-1}$ As and $20 \mathrm{mg} \mathrm{kg}^{-1}$ Cs. Means followed by the asterisk were significantly different compared with the control soil $(\mathrm{CK})$ at $P<0.05$

little decrease in the EXC fraction was shown in all samples. It may indicate that the EXC fraction of As in soil tended to transform to the SOL fraction upon EKF. With Cs addition of $20 \mathrm{mg} \mathrm{kg}^{-1}$, a slight increase in the SOL fraction was found in the middle and cathode areas $(0.82$ and $0.71 \mathrm{mg} \mathrm{kg}^{-1}$, respectively). However, Cs in the EXC fraction was significantly increased in the anode area (3.48 mg kg $\mathrm{m}^{-1}$ ) compared to that in the cathode $\left(0.36 \mathrm{mg} \mathrm{kg}^{-1}\right)$ which may suggest the Cs was more able to be adhered to adsorption sites of colloids in soil pore influenced by the EKF. Results of the SOL and EXC fractions indicated the comparable higher mobility and 

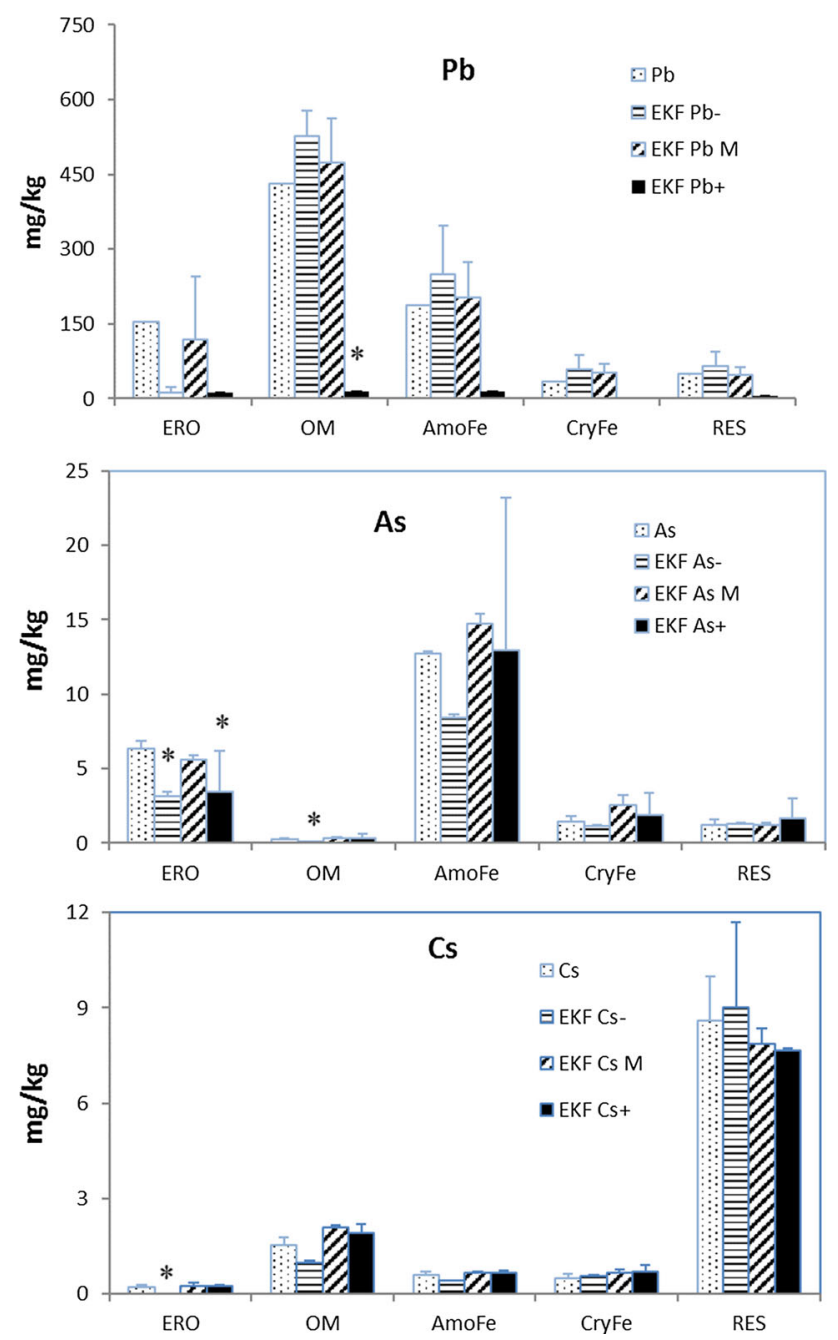

Fig. 8 Changes in selected solid-phase fractions of $\mathrm{Pb}$, As and $\mathrm{Cs}$ in soils with EKF in the anode $(+)$, cathode $(-)$, the middle region (M) between two electrodes, and the polluted soils without EKF $(\mathrm{Pb}$, As, Cs). Soil was contaminated with $600 \mathrm{mg} \mathrm{kg}^{-1} \mathrm{~Pb}, 20 \mathrm{mg} \mathrm{kg}^{-1}$ As and $20 \mathrm{mg} \mathrm{kg}^{-1}$ Cs. Means of each metal(loid) fraction followed by asterisks were significantly different compared with that of polluted soils without EKF

bioavailability of As and Cs. Larger addition of As and Cs and parameters in EKF such as the electrical field intensity may play important roles in further improving their mobility and bioavailability (Fig. 8).

Moreover, acidification transformed stable fractions (the $\mathrm{OM}$ and $\mathrm{AmoFe}$ fractions for $\mathrm{Pb}$, the AmoFe fraction for As and the RES for $\mathrm{Cs}$ ) into the $\mathrm{SOL}(\mathrm{Pb}$ and $\mathrm{As}$ ) and EXC (Cs) fractions in soils near the anode (Fig. 8). Low bioavailability constrains the phytoextraction efficiency of heavy metals (i.e., $\mathrm{Pb}$ ), while the changes of soil physicalchemical properties may enhance their availability and mobility. Plants have developed their own strategy for dissolving metals. Secretion of $\mathrm{H}^{+}$ions by roots will compete binding sites on soil particles with heavy metal cations. As a result, more metals are mobilized under acid condition around rhizosphere (Thangavel 2004). Moreover, activities of rhizospheric microbes significantly increase heavy metal bioavailability which results in the increase in the labile metal in soil (Sheoran et al. 2009). In addition to mobilization by plant itself, the solubility of metal(loid)s could also be enhanced by extraneous soil amendments such as chelating, complexing, organic and microbial agents (Bolan et al. 2014). However, there are still some limitations in applying soil amendments associated with phytoremediation. EDTA was the most common chelating agent for increasing water-soluble metal(loid) in soils (Han et al. 2004a, b). There is no standard for the additive amount of EDTA according to different types of soils and contaminated metal(loid)s. Therefore, excessive addition may cause the leaching of EDTA, plant phytotoxicity and the pollution of groundwater (Han et al. 2004a, b; Wu et al. 2004; Zhao et al. 2011). Engineered microorganisms are usually introduced to soil as microbial agents which effectively increase the mobility of metal(loid)s. However, they may disrupt the ecological balance of the soil environment and lead to species invasion as a consequence of competition with indigenous microorganisms (Roane et al. 2015). It was reported that the SOL fraction of $\mathrm{Pb}$ was dramatically increased in soil stimulated by EKR and the phytoremediation could remove $95 \%$ of $\mathrm{Pb}$ with an optimization of electrical field intensity and stimulation period (Yang and Lin 1998). EKP treatment also significantly decreased the dominant AmoFe As and CryFe As fractions by 42 and $10 \%$, respectively, and the removal of total As by phytoremediation increased to $32 \%$ after 4 weeks of EKR (Jeon et al. 2015). In addition, $58 \%$ of Cs was removed after 3 weeks of EKR with electrical field of $5 \mathrm{~V}$ (Kim et al. 2015). Without $\mathrm{pH}$ maintenance near the cathode, precipitation of metal(loid)s may be generated due to the high $\mathrm{OH}^{-}$concentration implying the decreased bioavailability of $\mathrm{Pb}$ and $\mathrm{Cs}$ in soils near the cathode.

However, some limitations appeared over the electrokinetic remediation. Gas species produced during water electrolysis as discussed above may be trapped near the surface of the electrodes thus increasing the resistance and significantly slowing the remediation process (Sah and Chen, 1998). This required initial low voltage with lower resistance in soil and progressive increase in the voltages due to increased resistance developed over the electrokinetic processes. Other possible species such as potential precipitated hydroxides of cations due to the increased $\mathrm{pH}$ around the 
cathode plugged the soil pores, subsequently hindering the electrical current and decreasing the diffusive flow over time when the voltage is applied (Sah and Chen 1998).

\section{Conclusion}

The native $\mathrm{Pb}$ in the MS River Delta paddy soils was mostly in the AmoFe, OM and RES fractions, the native As in the AmoFe, ERO and RES fractions, while Cs in the RES fraction. In general, added $\mathrm{Pb}$, As and $\mathrm{Cs}$ in paddy soils showed distinguished solid-phase distributions controlled by the nature of the element: $\mathrm{Pb}$ was dominantly present in the OM fraction (38-52\%); As in the AmoFe fraction (40-46\%); and Cs in the RES (62-68\%) and SOL + EXC (10-17 \%) fractions.

The solid-phase distributions of added $\mathrm{Pb}, \mathrm{As}$ and $\mathrm{Cs}$ were significantly influenced by the electrokinetic field. EKF treatment was efficient on lowering soil $\mathrm{pH}$ near to the anode through hydrolysis of water in releasing proton which is beneficial for the dissolution of metal(loid)s. The acidification in the anode region under EKF efficiently increased the SOL Pb (by 193 times) and EXC Cs (by 1.3 times) in the soils while possible electromigration of As anion from the cathode where As was solubilized at high $\mathrm{pH}$ may be responsible for building up of SOL As in the anode region (by 2.6 times). In addition, the SOL and EXC fractions progressively decreased from soils in the anode to the cathode areas which implied both acidification of $\mathrm{H}^{+}$, solubilization/mobilization of elements in the anode and possible precipitation in the cathode due to high $\mathrm{OH}^{-}$ concentration. The bioavailability of $\mathrm{Pb}$, As and $\mathrm{Cs}$ may increase upon EKF treatment due to their significant presence in the soluble and exchangeable forms, indicating the EKF treatment might be a good alternative for increasing metal(loid) bioavailability in phytoremediation of $\mathrm{Pb}$-, As- and Cs-contaminated soils. Further studies are required on $\mathrm{pH}$ maintenance near the cathode by using organic acids such as acetic acid and citric acid, optimizations of electrical parameters including electrical field intensity, current application mode, the distance between the electrodes and stimulation period and their enhancement on the mobility of bioavailability of metal(loid)s.

Acknowledgments This research was supported by U.S. Nuclear Regulatory Commission (NRC-HQ-84-15-G-0042 and NRC-HQ-12G-38-0038) and U.S. Department of Commerce (NOAA) (NA11SEC4810001-003499). Mr. Mao was also supported by China Scholarship Council, Jiangsu Scientific Research Innovation Program of Ordinary Higher Education Graduate (KYZZ0156), Special Fund for Hydro-scientific Research in the Public Interest (201301017), and the Fundamental Research Fund for the Central Universities (2014B04814 and 2015B05814).

\section{Abbreviations}

$\begin{array}{ll}\text { EKF } & \text { Electrokinetic field } \\ \text { EKR } & \text { Electrokinetic remediation } \\ \text { SOL } & \text { The water-soluble fraction } \\ \text { EXC } & \text { The exchangeable fraction } \\ \text { ERO } & \text { The easily reducible oxide bound fraction } \\ \text { AmoFe } & \text { Amorphous iron oxide bound fraction } \\ \text { OM } & \text { Organic matter bound fraction } \\ \text { CryFe } & \text { Crystalline iron oxide bound fraction } \\ \text { RES } & \text { Residual bound fraction } \\ \text { SSD } & \text { Selective sequential dissolution } \\ \text { ICP-MS } & \text { Inductively coupled plasma mass } \\ & \text { spectrometry }\end{array}$

\section{References}

Adriano DC (2001) Trace elements in terrestrial environments: biogeochemistry, bioavailability, and risks of metals, 2nd edn. Springer, New York

Altin A, Degirmenci M (2005) Lead (II) removal from natural soils by enhanced electrokinetic remediation. Sci Total Environ 337(1-3):1-10

Banin A, Navrot J, Perl A (1987) Thin-horizon sampling reveals highly localized concentrations of atmophile heavy metals in a forest soil. Sci Total Environ 61:145-152

Bolan N, Kunhikrishnan A, Thangarajan R, Kumpiene J, Park J, Makino T, Kirkham MB, Scheckel K (2014) Remediation of heavy metal(loid)s contaminated soils-to mobilize or to immobilize? J Hazard Mater 266:141-166

Cameselle C, Reddy KR (2012) Development and enhancement of electro-osmotic flow for the removal of contaminants from soils. Electrochim Acta 86:10-22

Cameselle C, Chirakkara RA, Reddy KR (2013) Electrokineticenhanced phytoremediation of soils: status and opportunities. Chemosphere 93(4):626-636

Davies BE (1980) Applied soil trace elements. Wiley, New York

Dermont G, Bergeron M, Mercier G, Richer-Laflèche M (2008) Soil washing for metal removal: a review of physical/chemical technologies and field applications. J Hazard Mater 152(1):1-31

Foster AL, Brown GE, Tingle TN, Parks GA (1998) Quantitative arsenic speciation in mine tailings using X-ray absorption spectroscopy. Am Mineral 83:553-568

Giannakopoulou F, Haidouti C, Chronopoulou A, Gasparatos D (2007) Sorption behavior of cesium on various soils under different pH levels. J Hazard Mater 149(3):553-556

Gommers A, Gafvert T, Smolders E, Merckx R, Vandenhove H (2005) Radio cesium soil-to-wood transfer in commercial willow short rotation coppice on contaminated farm land. J Environ Radioact 78:267-287

Han FX, Banin A (1996) Solid-phase manganese fractionation changes in saturated arid-zone soils: pathways and kinetics. Soil Sci Soc Am J 60(4):1072-1080

Han FX, Banin A (1997) Long-term transformations and redistribution of potentially toxic heavy metals in arid-zone soils. I: under saturated conditions. Water Air Soil Pollut 95(1-4):399-423

Han FX, Banin A (1999) Long-term transformations and redistribution of potentially toxic heavy metals in arid-zone soils. II: under 
the field capacity regime. Water Air Soil Pollut 114(3-4):221-250

Han FX, Su Y, Maruthi Sridhar BB, Monts DL (2004a) Distribution, transformation and bioavailability of trivalent and hexavalent chromium in contaminated soil. Plant Soil 265(1-2):243-252

Han FX, Kingery WL, Selim HM, Gerard PD, Cox MS, Oldham JL (2004b) Arsenic solubility and distribution in poultry waste and long-term amended soil. Sci Total Environ 320(1):51-61

Han FX, Su Y, Monts DL, Waggoner CA, Plodinec MJ (2006) Binding, distribution, and plant uptake of mercury in a soil from Oak Ridge, Tennessee, USA. Sci Total Environ 368(2-3):753-768

Han FX, Kingery WL, Hargreaves JE, Walker TW (2007) Effects of land uses on solid-phase distribution of micronutrients in selected vertisols of the Mississippi River Delta. Geoderma 142(1-2):96-103

Han FX, Shiyab S, Chen J, Su Y, Monts DL, Waggoner CA, Matta FB (2008) Extractability and bioavailability of mercury from a mercury sulfide contaminated soil from Oak Ridge, Tennessee, USA. Water Air Soil Pollut 194(1-4):67-75

Han FX, Su Y, Shi Z, Xia Y, Tian W, Philips V, Monts DL, Gu M, Liang Y (2012) Mercury distribution and speciation in floodplain soils and uptake into native earthworms (Diplocardia spp.). Geoderma 170:261-268

Huang ZY, Xie H, Cao YL, Cai C, Zhang Z (2014) Assessing of distribution, mobility and bioavailability of exogenous $\mathrm{Pb}$ in agricultural soils using isotopic labeling method coupled with BCR approach. J Hazard Mater 266:182-188

Iannelli R, Masi M, Ceccarini A, Ostuni MB, Lageman R, Muntoni A, Spiga D, Polettini A, Marini A, Pomi R (2015) Electrokinetic remediation of metal-polluted marine sediments: experimental investigation for plant design. Electrochim Acta 181:146-159

Jeon EK, Ryu SR, Baek K (2015) Application of solar-cells in the electrokinetic remediation of As-contaminated soil. Electrochim Acta 181:160-166

Kabata-Pendias A (2000) Trace elements in soils and plants, 3rd edn. CRC Press, Boca Raton

Kashparov V, Colle C, Zvarich S, Yoschenko V, Levchuk S, Lundin S (2005) Soil-to-plant halogens transfer studies 1. Root uptake of radioiodine by plants. J Environ Radioact 79:187-204

Kersting AB, Efurd DW, Finnegan DL, Rokop DJ, Smith DK, Thompson JL (1999) Migration of plutonium in ground water at the Nevada Test Site. Nature 397:56-59

Kim KJ, Cho JM, Beak K, Yang JS, Ko SH (2010) Electrokinetic removal of chloride and sodium from tidelands. J Appl Electrochem 40(6):1139-1144

Kim GN, Kim SS, Park UR, Moon JK (2015) Decontamination of soil contaminated with cesium using electrokinetic-electrodialytic method. Electrochim Acta 181:233-237

Lee HH, Yang JW (2000) A new method to control electrolytes pH by circulation system in electrokinetic soil remediation. J Hazard Mater 77(1-3):227-240

Lu P, Feng Q, Meng Q, Yuan T (2012) Electrokinetic remediation of chromium- and cadmium-contaminated soil from abandoned industrial site. Sep Purif Technol 98:216-220

Mandal B (2002) Arsenic round the world: a review. Talanta 58(1):201-235

Marabottini R, Stazi SR, Papp R, Grego S, Moscatelli MC (2013) Mobility and distribution of arsenic in contaminated mine soils and its effects on the microbial pool. Ecotoxicol Environ Saf 96:147-153

Nyamangara J (1998) Use of sequential extraction to evaluate zinc and copper in a soil amended with sewage sludge and inorganic metal salts. Agric Ecosyst Environ 69(2):135-141
Ottosen LM, Pedersen AJ, Hansen HK, Ribeiro AB (2007) Screening the possibility for removing cadmium and other heavy metals from wastewater sludge and bio-ashes by an electrodialytic method. Electrochim Acta 52(10):3420 3426

Pérez-Esteban J, Escolástico C, Moliner A, Masaguer A (2013) Chemical speciation and mobilization of copper and zinc in naturally contaminated mine soils with citric and tartaric acids. Chemosphere 90(2):276-283

Porter EK, Peterson PJ (1977) Arsenic tolerance in grasses growing on mine waste. Environ Pollut 14(4):255-265

Prasad PVV (2003) Plant nutrition: iron chlorosis. In: Thomas B, Murphy DJ, Murray BG (eds) Encyclopedia of applied plant sciences. Elsevier, London, pp 649-656

Pulford ID, Watson C (2003) Phytoremediation of heavy metalcontaminated land by trees-a review. Environ Int 29(4):529-540

Puppala SK, Alshawabkeh AN, Acar YB, Gale RJ, Bricka M (1997) Enhanced electrokinetic remediation of high sorption capacity soil. J Hazard Mater 55(1-3):203-220

Raskin I, Ensley BD (2000) Phytoremediation of toxic metals: using plants to clean the environment. Wiley, New York

Roane TM, Pepper LL, Gentry TL (2015) Microorganisms and metal pollutants. In: Pepper LL, Gerba CP, Gentry TJ (eds) Environmental microbiology. Academic Press, Salt Lake City, pp 415-439

Sah JG, Chen JY (1998) Study of the electrokinetic process on Cd and $\mathrm{Pb}$-spiked soils. J Hazard Mater 58:301-315

Saichek RE, Reddy KR (2003) Effect of pH control at the anode for the electrokinetic removal of phenanthrene from kaolin soil. Chemosphere 51(4):273-287

Salazar MJ, Pignata ML (2014) Lead accumulation in plants grown in polluted soils. Screening of native species for phytoremediation. J Geochem Explor 137:29-36

Sheoran V, Sheoran AS, Poonia P (2009) Phytomining: a review. Miner Eng 22(12):1007-1019

Shotyk W, Norton SA, Farmer JG (1997) Summary of the workshop of peat bog archives of atmospheric metal deposition. Water Air Soil Pollut 100(3-4):213-219

Smith E, Naidu R, Alston AM (1998) Arsenic in the soil environment: a review. Adv Agron 64:149-195

Tessier A, Campbell PGC, Bisson M (1979) Sequential extraction procedure for the speciation of particulate trace metals. Anal Chem 51(7):844-851

Thangavel PSC (2004) Phytoextraction: role of hyperaccumulators in metal contaminated soils. Proc Indian Natl Sci Acad 70(1):109-130

Virkutyte J, Sillanpää M, Latostenmaa P (2002) Electrokinetic soil remediation-critical overview. Sci Total Environ 289(1-3):97-121

Wu L, Luo Y, Xing X, Christie P (2004) EDTA-enhanced phytoremediation of heavy metal contaminated soil with Indian mustard and associated potential leaching risk. Agric Ecosyst Environ 102(3):307-318

Yang GC, Lin SL (1998) Removal of lead from a silt loam soil by electrokinetic remediation. J Hazard Mater 58(1-3):285299

Yasunari TJ, Stohl A, Hayano RS, Burkhart JF, Eckhardt S, Yasunari $\mathrm{T}$ (2011) Cesium-137 deposition and contamination of Japanese soils due to the Fukushima nuclear accident. Proc Natl Acad Sci 108(49):19530-19534

Yeung AT, Gu YY (2011) A review on techniques to enhance electrochemical remediation of contaminated soils. J Hazard Mater 195:11-29 
Yeung A, Gu Y (2012) Use of chelating agents in electrochemical remediation of contaminated soil. In: Tsang DCW, Lo IMC, Surampalli RY (eds) Chelating agents for land decontamination technologies. American Society of Civil Engineers, Reston, pp 212-280
Zhao S, Lian F, Duo L (2011) EDTA-assisted phytoextraction of heavy metals by turfgrass from municipal solid waste compost using permeable barriers and associated potential leaching risk. Bioresour Technol 102(2):621-626 